\title{
Studies of the Nutritional Requirements of Poteriochromonas stipitata
}

\author{
BY HENRY D. ISENBERG \\ Department of Laboratories, The Long Island Jewish Hospital, \\ New Hyde Park, N.Y., U.S.A.
}

(Received 11 September 1961)

\begin{abstract}
SUMMARY
The nutritional requirements of the phagotrophic phytoflagellate Poteriochromonas stipitata are defined. Minerals, glucose, ammonium-nitrogen and the vitamins thiamine, biotin and vitamin $B_{12}$ are essential for the growth of this chrysomonad. The addition of $\mathrm{L}$-isoleucine, L-leucine, L-valine and L-phenylalanine increases the yield of organism at least fivefold. Further augmentation with adenine, L-glutamic acid, L-histidine and L-arginine provides optimal nutrition for the organism.
\end{abstract}

\section{INTRODUCTION}

This paper reports a study of the nutritional requirements of Poteriochromonas stipitata American Type Culture Collection (ATCC) no. 11531, a freshwater phytoflagellate closely related to Ochromonas malhamensis (Pringsheim, 1952).

\section{METHODS}

Poteriochromonas stipitata ATCC no. 11531 was maintained in a medium consisting of (g./l.): powdered milk, 2.0; trypticase (Baltimore Biological Laboratories, BBL, Baltimore, Md., U.S.A.), 0.5; sucrose, 1.0 ; adjusted to $\mathrm{pH} \mathrm{5.0.} \mathrm{Ten} \mathrm{ml.} \mathrm{volumes} \mathrm{of}$ medium were dispensed in $25 \mathrm{ml}$. Erlenmeyer flasks fitted with cottonwool plugs and sterilized by autoclaving at $121^{\circ}$ for $15 \mathrm{~min}$. Thioglycollate broth (BBL), prepared and autoclaved according to the instructions of the manufacturer, could also be used for maintenance. The defined medium described by Hutner, Provasoli \& Filfus (1953) for use with freshwater chrysomonads served as a medium for comparison (Table 1). It was dispensed in $10 \mathrm{ml}$. quantities into micro-Fernbach flasks, which were then closed with inverted glass tumblers and autoclaved for $15 \mathrm{~min}$. at $121^{\circ}$. The basal medium $A$ for evaluating possible nutrients was composed as shown in Table 1. The basal media were always prepared without the trace metals and vitamin solutions and autoclaved for $15 \mathrm{~min}$. at $121^{\circ}$. The medium was adjusted to pH 5 or 7 . The $100 \times$ concentrated trace metal and vitamin solutions (Table 1 ) were sterilized by filtration through ultrafine sintered glass, and stored in sterile glassstoppered brown bottles. The trace metal and vitamin solutions were added in $10 \mathrm{ml} / \mathrm{l}$. amounts after the rest of the medium had been autoclaved.

Nutritional experiments were done in $25 \mathrm{ml}$. micro-Fernbach flasks, covered with inverted rimless tumblers. The total volume of medium in these flasks never exceeded $10 \mathrm{ml}$. The experimental vessels were incubated in stainless steel transfer hood

Vol. 29, No. 2 was issued 15 October 1962 
provided with a glass window and illuminated by two $50 \mathrm{~W}$. daylight fluorescent bulbs. Temperature in this hood ranged from $22-25^{\circ}$. Cells for inoculation were washed thrice with sterile $\mathrm{m} / 30$ phosphate buffer $(\mathrm{pH} 5 \cdot 6$ ), the original volume restored and each experimental vessel inoculated with $0.05 \mathrm{ml}$. Aseptic precautions were observed throughout. For studies in the dark a $\mathbf{2 5}^{\circ}$ incubator was used. Since illumination exerted no appreciable effect on yields, all results represent experiments conducted in the light unless stated otherwise.

Table 1. Constituents of various media used (g./l.)

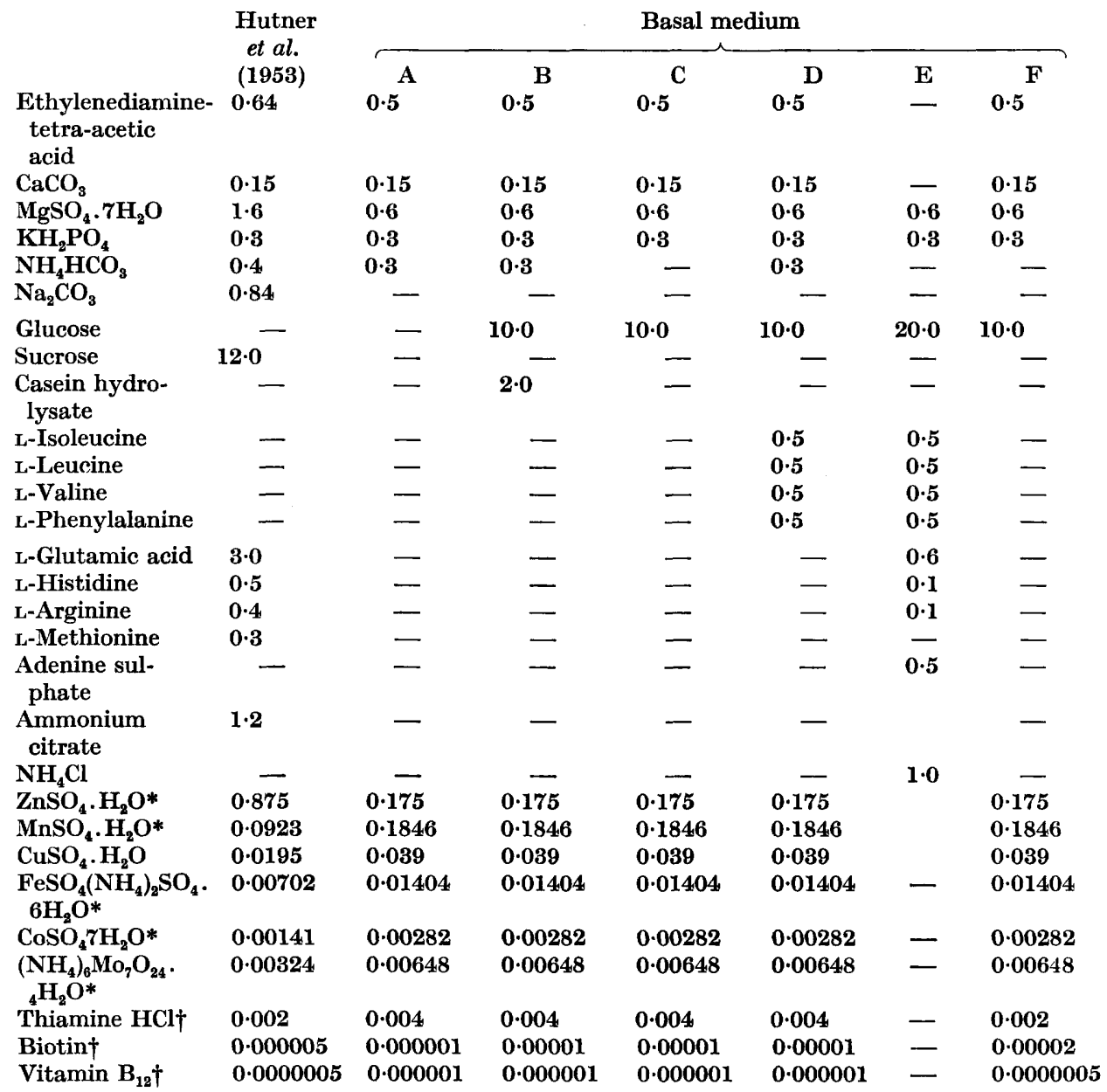

* Trace-metals prepared as concentrate, sterilized by filtration and added as $10.0 \mathrm{ml} . / \mathrm{l}$. after autoclaving.

$\dagger$ Vitamins prepared separately but exactly as trace metal solution and added after autoclaving. pH 5 or $\mathrm{pH} 7$.

All materials which were known to be stable when autoclaved at $121^{\circ}$ for $15 \mathrm{~min}$. were added before heat sterilization. Heat-labile materials were usually dissolved in the basal medium A and passed through sterile ultrafine sintered-glass filters. All 
experiments were done in quadruplicate and repeated five times. Modifications of media were made as required.

Tests for sterility were performed on all materials and solutions and the inocula were examined for contaminants; the media used for these purposes were Eugon (BBL) and anaerobic (BBL) agars; solid media were preferred since the chrysomonad itself is inhibited by agar.

To ensure inocula of uniform physiological activity and age, $2 \mathrm{ml}$. of maintenance culture were transferred to $2 \mathrm{l}$. Fernbach flasks containing $600 \mathrm{ml}$. basal medium B (Table 1). A sterile Tephlon-coated iron bar was then introduced and the mixture gently agitated with a magnetic stirrer. Measurement of growth of Poteriochromonas stipitata was determined after 14 days incubation by the estimation of total cellular-nitrogen according to the method described by Umbreit, Burris \& Stauffer (1957) with albumin (Armour) and ammonium sulphate as standards. Organisms were prepared for analysis by transferring $10 \mathrm{ml}$. of culture to $15 \mathrm{ml}$. conical tubes and centrifuging at $1150 \mathrm{~g}$ at $5^{\circ}$ for $10 \mathrm{~min}$. The packed organisms were washed thrice with $\mathrm{m} / 30$ phosphate buffer $(\mathrm{pH} 5 \cdot 6)$.

Chlorophyll was determined according to methods described jby Wolken \& Palade (1953) and Strain (1949). Since the acetone extracts displayed greater differences of extinction, this solvent was used. For quantitative results, nitrogen determinations were made on samples of the acetone extracts.

\section{RESULTS}

\section{Carbon sources}

Table 2 lists the few compounds which satisfied the carbon requirements of Poteriochromonas stipitata. The following materials (at $0.056 \mathrm{M}$ ) did not fulfil this requirement: lactose, ribose, xylose, rhamnose, calcium, gluconate, potassium pyruvate, sodium lactate, sodium citrate, $\alpha$-ketoglutarate, sodium succinate,

Table 2. Total cell-nitrogen of Poteriochromonas stipitata produced while growing on various single carbon sources

Basal medium A was used and the compounds added to $0.056 \mathrm{~m}$ unless stated otherwise. Experiments were made at pH 5.0 in the light. The numbers represent the mean values of five experiments each performed in quadruplicate. Basal medium $A$ without an organic carbon source did not support the growth of the organism.

$\begin{array}{lclc}\text { Carbon source } & \begin{array}{c}\text { Total cell-N } \\ (\mu \mathrm{g} . / \mathrm{ml} . \text { culture })\end{array} & \text { Carbon source } & \begin{array}{c}\text { Total cell-N } \\ (\mu \mathrm{g} . / \mathrm{ml} \text {. culture })\end{array} \\ \text { Glucose } & \mathbf{4 1 \cdot 8 3} & \text { Starch }(\mathbf{5} \%, \mathbf{w} / \mathrm{v}) & \mathbf{9 5 \cdot 2 9} \\ \text { Fructose } & \mathbf{3 3 \cdot 8 1} & \text { Glycogen }(5 \%, \mathbf{w} / \mathrm{v}) & \mathbf{7 5 \cdot 8 6} \\ \text { Galactose } & \mathbf{4 1 \cdot 8 3} & \text { Raffinose } & \mathbf{5 1 \cdot 3 1} \\ \text { Mannose } & \mathbf{1 1 \cdot 2 7} & \text { Glycerol } & \mathbf{3 5 \cdot 3 9} \\ \text { Sucrose } & \mathbf{4 3 \cdot 7 5} & \text { Sodium acetate } & \mathbf{1 4} \cdot 19 \\ \text { Maltose } & \mathbf{4 4 \cdot 7 1} & \text { Ethanol } & \mathbf{1 5 \cdot 9 6}\end{array}$

sodium fumarate, sodium propionate, sodium butyrate, glycollic acid, sodium glutamate, L-asparagine, L-glutamine, cholesterol, sitosterol, ribonucleic acid, deoxyribonucleic acid, acetone, methyl formate, ethyl formate, $n$-propyl formate, $n$-butyl formate, ethylene glycol, acetaldehyde, tricarboxylic acid and hexose monophosphate shunt intermediates, simple esters, fatty acids, steroids, and nucleic acids. 
When judged on the basis of $\mu \mathrm{g}$ total cell-N per carbon atom of substrate, acetate and ethanol were as effective as the hexoses, while glycerol was better. Thus the total cell-N per carbon atom of glycerol was almost $12 \mu \mathrm{g}$., while glucose yielded only $7 \mu \mathrm{g}$. on the same basis. The ineffective carbon sources were re-examined for their action on the growth of $\boldsymbol{P}$. stipitata in the presence of glucose. None had any effect except citrate which inhibited growth, probably because it bound trace metals; the joint addition of iron and magnesium abolished the inhibition.

The optimal concentration of glucose (Fig. 1) was determined for several media. Regardless of the nutrient environment and presence or absence of illumination the optimal glucose concentration was about $20 \mathrm{~g}$. $/$., i.e. $0 \cdot 112 \mathrm{M}$. In the basal medium $\mathrm{B}$ a slight but definite increase in total cell-N occurred with illumination.

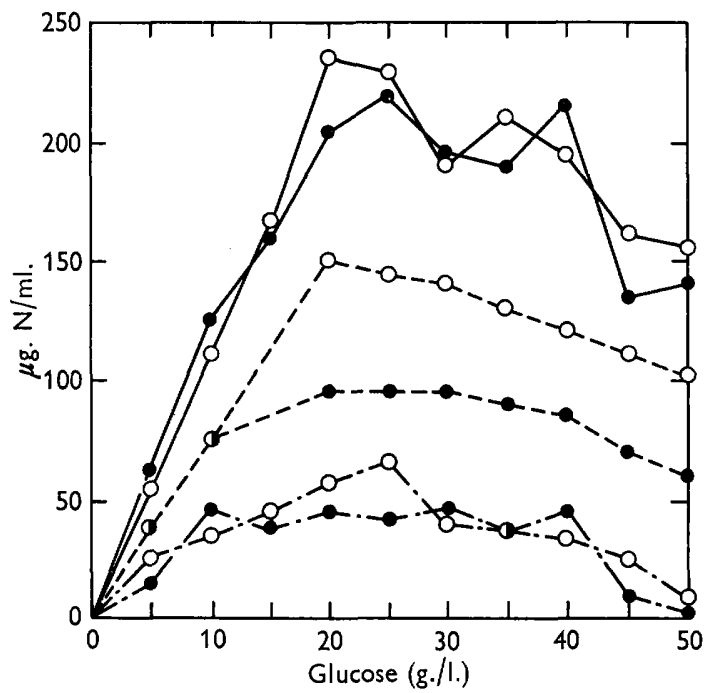

Fig. 1. Response of Poteriochromonas stipitata to glucose while growing in various media at pH 5.0. O— $\longrightarrow$, Medium $\mathrm{E}+$ trace metals + vitamins in light; - -o, medium $\mathrm{E}+$ trace metals + vitamins in dark; $\bigcirc---O$, Hutner's defined medium (Hutner et al. 1953) in light;

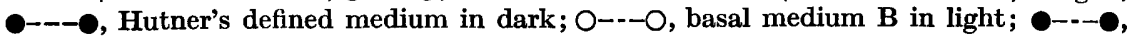
basal medium $\mathbf{B}$ in dark.

The ability of Poteriochromonas stipitata to utilize acetate as a sole carbon source suggested a possible connexion between this organism and the 'acetate flagellates' (Hutner \& Provasoli, 1951). Figure 2 shows that 0.1 M acetate was definitely inhibitory for $\boldsymbol{P}$. stipitata. Since the 'acetate flagellates' flourish at this concentration of the compound, $\boldsymbol{P}$. stipitata cannot be considered a member of this group. Ethyl formate was not used as a carbon source, although this ester is in equilibrium with ethanol and formic acid when in solution and the organism can utilize ethanol as a carbon source. Ethyl formate did not inhibit the growth of $\boldsymbol{P}$. stipitata when added to media containing glucose, but the ester as well as formic acid prevented proliferation of $\boldsymbol{P}$. stipitata when ethanol or acetate were substituted for the hexose. 


\section{Nitrogen sources}

Basal medium $\mathrm{C}$ was inadequate for growth. Several nitrogenous compounds were then examined for their ability to serve as nitrogen sources, either alone, with casein hydrolysate (BBL), or with casein hydrolysate (BBL) + ammonium bicarbonate. The latter is the major nitrogen source advocated by Hutner et al. (1953). The findings are presented in Table 3. Nitrate or nitrite in the concentrations shown inhibited growth. However, sodium nitrate $1.0 \mathrm{~g} . / 1$. resulted in good crops. Nitrite did not support growth at any concentration tested. The capacity of the chrysomonad to utilize urea as sole nitrogen source at $\mathrm{pH} 5$ and 7 , and to the same degree or better than on the casein hydrolysate (BBL) and casein hydrolysate (BBL)+ ammonium bicarbonate controls, was surprising; no extracellular urease was demonstrable in the culture fluid. When such cell-free supernatant fluid was added to urea in a neutral buffer, liberation of ammonia did not occur even after prolonged incubation.

Table 3. The growth of Poteriochromonas stipitata with various nitrogen sources

The basal medium $\mathrm{C}$ at $\mathrm{pH} \mathbf{5 . 0}$ was used. The flasks were illuminated during the experiment. Casein hydrolysate (BBL) 2 g./l. and $\mathrm{NH}_{4} \mathrm{HCO}_{3} \mathrm{0} \cdot 3 \mathrm{~g}$./ $/$. were added to basal medium $\mathrm{C}$. The numbers represent the mean values of five experiments each performed in quadruplicate.

Nitrogen source (g./1.)

$\begin{array}{lc}\text { No addition } & 0 \\ \mathrm{NaNO}_{3} & \mathbf{2 \cdot 3} \\ \mathrm{NaNO}_{2} & \mathbf{1} \cdot 86 \\ \text { Urea } & \mathbf{0 \cdot 8} \\ \mathrm{NH}_{2} \mathrm{OH} . \mathrm{HCl} & \mathbf{1} \cdot 88 \\ \text { Human serum } & \mathbf{1 0} \\ \text { Gelatin } & \mathbf{2 \cdot 5} \\ \text { Trypticase (BBL) } & \mathbf{2 \cdot 5} \\ \text { Phytone (BBL) } & \mathbf{2 \cdot 5} \\ \text { Polypeptone (BBL) } & \mathbf{2 \cdot 5} \\ \text { Thiotone (BBL) } & \mathbf{2 \cdot 5}\end{array}$

\begin{tabular}{|c|c|c|}
\hline \multicolumn{3}{|c|}{ Media } \\
\hline $\begin{array}{c}\text { Basal C } \\
\text { alone }\end{array}$ & $\begin{array}{c}\text { Basal C+ } \\
\text { casein } \\
\text { hydrolysate } \\
\text { Total cell-N }(\mu \mathrm{g} . / \mathrm{ml} \text {. }\end{array}$ & $\begin{array}{l}\text { Basal C+ } \\
\text { hydrolysate } \\
+\mathrm{NH}_{4} \mathrm{HCO}_{3} \\
\text { re) }\end{array}$ \\
\hline 1.96 & $18 \cdot 27$ & $26 \cdot 66$ \\
\hline $1 \cdot 03$ & $13 \cdot 02$ & $19 \cdot 95$ \\
\hline $1 \cdot 89$ & $1 \cdot 79$ & $1 \cdot 83$ \\
\hline $30 \cdot 73$ & $61 \cdot 04$ & $38 \cdot 50$ \\
\hline $1 \cdot 87$ & $1 \cdot 87$ & $1 \cdot 87$ \\
\hline $11 \cdot 09$ & $22 \cdot 54$ & $46 \cdot 20$ \\
\hline $38 \cdot 08$ & $31 \cdot 41$ & $37 \cdot 45$ \\
\hline $30 \cdot 31$ & $39 \cdot 38$ & $73 \cdot 41$ \\
\hline $23 \cdot 36$ & $33 \cdot 08$ & $4,2 \cdot 00$ \\
\hline $40 \cdot 46$ & $54 \cdot 43$ & $60 \cdot 69$ \\
\hline 33.08 & $40 \cdot 86$ & $61 \cdot 25$ \\
\hline
\end{tabular}

Amino acid requirements. Table 3 also shows that the stimulatory effect of casein hydrolysate $(\mathrm{BBL}) 2 \mathrm{~g}$./l. was considerable, regardless of the nature of the other nitrogen sources tested, except in the cases of nitrite and hydroxylamine, which were inhibitory. Therefore, various amino acids were tested for stimulatory activity. The

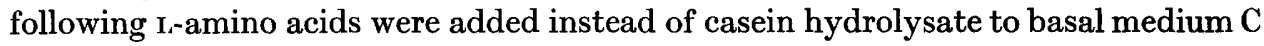
in amounts which corresponded to their concentration in $2 \mathrm{~g}$./1. casein hydrolysate (g./l.): glutamic acid, 0.432 ; proline, 0.232 ; glycine, 0.038 ; serine, 0.125 ; threonine, $0 \cdot 105$; tyrosine, $0 \cdot 127$; isoleucine, $0 \cdot 122$; leucine, $0 \cdot 189$; valine, $0 \cdot 139$; aspartic acid 0.153 ; histidine, 0.061 ; arginine, 0.078 ; methionine, 0.058 ; cystine, 0.007 ; alanine, 0.067; phenylalanine, 0.099 ; tryptophan, 0.026. Leucine, isoleucine, valine, and phenylalanine additions resulted in yields of organism comparable with those obtained with casein hydrolysate. Therefore, these amino acids were added in 
increasing concentrations singly and in mixtures to basal medium C. Results showed that $0.5 \mathrm{~g} . /$ l. was the most favourable concentration for these amino acids. Total cell-N values greater than for casein hydrolysate were obtained almost uniformly with these amino acids by themselves or in various mixtures as shown in Table 4.

Table 4. The influence of casein hydrolysate and amino acids on total cellnitrogen yields of Poteriochromonas stipitata

Casein hydrolysate (BBL) content was $2 \mathrm{~g} . / \mathrm{l}$. while the amino acids were added in $0.5 \mathrm{~g}$. $/ 1$. amounts each for the same volume. The basal medium $\mathrm{C}$ was used at $\mathrm{pH} 5 \cdot 0$, and the flasks were illuminated.

\begin{tabular}{|c|c|c|c|}
\hline Amino $\operatorname{acid}(s)$ & $\begin{array}{c}\text { Total cell-N } \\
\text { (\% as compared } \\
\text { with casein } \\
\text { hydrolysis) }\end{array}$ & Amino acid(s) & $\begin{array}{c}\text { Total cell-N } \\
\text { (\% as compared } \\
\text { with casein } \\
\text { hydrolysis) }\end{array}$ \\
\hline Casein hydrolysate & $100 \cdot 0$ & Leucine, isoleucine & $128 \cdot 1$ \\
\hline $\begin{array}{l}\text { Phenylalanine, valine, } \\
\text { leucine, isoleucine }\end{array}$ & $181 \cdot 7$ & $\begin{array}{l}\text { Phenylalanine, leucine, } \\
\text { isoleucine }\end{array}$ & $161 \cdot 2$ \\
\hline Phenylalanine & $106 \cdot 3$ & Phenylalanine, valine, & $191 \cdot 2$ \\
\hline Valine & $111 \cdot 3$ & isoleucine & \\
\hline Leucine & $105 \cdot 6$ & Phenylalanine, valine, & $86 \cdot 5$ \\
\hline Isoleucine & $107 \cdot 5$ & leucine & \\
\hline Valine, leucine & $128 \cdot 1$ & Valine, leucine, iso- & $139 \cdot 5$ \\
\hline Valine, isoleucine & $122 \cdot 3$ & leucine & \\
\hline
\end{tabular}

\section{Table 5. The optimal concentration of certain amino acids for adequate and optimal nutrition of Poteriochromas stipitata}

The basal medium for testing these amino acids was identical with that used in Table 4; the experiments were conducted at $\mathrm{pH} 7 \cdot 0$ as well as $\mathrm{pH} 5 \cdot 0$, with illumination. Casein hydrolysate served as the control. The values obtained with these combined concentrations of the amino acids exceeded the control yields by at least $100 \%$.

\begin{tabular}{|c|c|c|c|}
\hline \multirow[b]{2}{*}{ Amino acids } & \multirow[b]{2}{*}{ g./l. } & \multicolumn{2}{|c|}{ Requirement* for } \\
\hline & & $\begin{array}{l}\text { Adequate } \\
\text { nutrition }\end{array}$ & $\begin{array}{c}\text { Optimal } \\
\text { nutrition }\end{array}$ \\
\hline L-Isoleucine & $0 \cdot 5$ & + & + \\
\hline L-Leucine & $0 \cdot 5$ & + & + \\
\hline L-Valine & $0 \cdot 5$ & + & + \\
\hline L-Phenylalanine & $0 \cdot 5$ & + & + \\
\hline L-Glutamic acid & $0 \cdot 6$ & . & + \\
\hline L-Histidine & $0 \cdot 1$ & . & + \\
\hline L-Arginine & $0 \cdot 1$ & . & + \\
\hline
\end{tabular}

* See Table 11 for definition of nutritional states.

It is quite difficult to consider these findings without comparing them with results obtained with Hutner's defined medium (Hutner et al. 1953, Table 1). At pH 5, comparable yields of organism were obtained; yet arginine, glutamic acid, histidine and methionine were present in Hutner's defined medium without the amino acids found to be stimulatory in the present work. When the above amino acids of Hutner's defined medium were added to basal medium $D$ (Table 1 ) or to the basal medium B, four times the total cell-N obtained with Hutner's defined medium was 
obtained, and at least twice the total cell-N with the basal medium B. To establish the optimal concentration of stimulatory amino acids, tolerance tests with each amino acid singly or in mixtures were performed. The results of these determinations indicated that optimal growth of Poteriochromonas stipitata was obtained with the concentrations shown in Table 5. These concentrations were equally effective at pH 5 and 7. The remaining amino acids found in casein exerted no stimulatory effect. Indifferent amino acids could, however, substitute as nitrogen sources in the absence of the stimulatory amino acids. Under these conditions yields of organism amounted to about one-third to one-half those obtained with casein hydrolysate (2 g./l.). Methionine by itself, however, was found to decrease the total yields of organism considerably and in concentrations as low as $0.1 \mathrm{~g} . / 1$. to abolish chlorophyll production. On the other hand, glutamic acid increased the chlorophyll content (acetone-extractable fraction absorbing at $650 \mathrm{~m} \mu$ ), the production of which was enhanced by this addition regardless of the conditions of illumination. This effect could not be reproduced with succinic acid, glycine or $\delta$-amino levulinic acid.

Table 6. The effect on the growth of Poteriochromonas stipitata of precursors, derivatives and antagonists of purines and pyrimidines

The medium used for these experiments was basal medium $\mathbf{A}$ to which glucose and casein hydrolysate were added in the usual concentrations, at $\mathrm{pH} \mathrm{5.0}$ and with illumination.

\begin{tabular}{|c|c|c|c|c|c|}
\hline Substance & $\begin{array}{c}\text { Concentration } \\
(\mathrm{g} . / \mathrm{I} .)\end{array}$ & $\begin{array}{c}\text { Total cell-N } \\
\text { (\% as com- } \\
\text { pared with } \\
\text { no addi- } \\
\text { tion }=100)\end{array}$ & Substance & $\begin{array}{c}\text { Concentration } \\
(\mathrm{g} \cdot / \mathrm{I} .)\end{array}$ & $\begin{array}{c}\text { Total cell-N } \\
\text { (\% as com- } \\
\text { pared with } \\
\text { no addi- } \\
\text { tion }=100)\end{array}$ \\
\hline No addition & $\mathbf{0}$ & $100 \cdot 0$ & Ureidosuccinic & $0 \cdot 39$ & $111 \cdot 4$ \\
\hline $\begin{array}{l}\text { Sodium ribo- } \\
\text { nucleate }\end{array}$ & 20 & $180 \cdot 9$ & $\begin{array}{l}\text { acid } \\
\text { 4-amino imida- }\end{array}$ & $2 \cdot 17$ & \\
\hline $\begin{array}{l}\text { Sodium deoxy- } \\
\text { ribonucleate }\end{array}$ & $0 \cdot 5$ & $264 \cdot 9$ & $\begin{array}{l}\text { zole-5-carbox- } \\
\text { amide. HCl }\end{array}$ & & \\
\hline Adenine & $0 \cdot 7$ & $193 \cdot 2$ & 6-Chloropurine & $0 \cdot 2$ & 71.5 \\
\hline Hypoxanthine & 0.5 & $111 \cdot 1$ & 6-Mercaptopurine & $0 \cdot 18$ & $69 \cdot 4$ \\
\hline Guanine & $0 \cdot 6$ & $97 \cdot 4$ & Barbital & $0 \cdot 22$ & $180 \cdot 0$ \\
\hline Xanthine & $0 \cdot 2$ & $160 \cdot 0$ & Kinetin & $0 \cdot 15$ & $183 \cdot 3$ \\
\hline Uric acid & $0 \cdot 19$ & $66 \cdot 4$ & Furfurylacetate & $0 \cdot 196$ & $80 \cdot 9$ \\
\hline Allantoin & $0 \cdot 375$ & $105 \cdot 3$ & Furfurylamine & $0 \cdot 122$ & $149 \cdot 2$ \\
\hline Thymine & $0 \cdot 135$ & $125 \cdot 1$ & Furan & 0.095 & $100 \cdot 9$ \\
\hline Uracil & $0 \cdot 15$ & $110 \cdot 9$ & 2-Furamide & $0 \cdot 155$ & $56 \cdot 1$ \\
\hline Cytosine & $\mathbf{2} \cdot \mathbf{0}$ & $129 \cdot 6$ & Furoic acid & $0 \cdot 157$ & $36 \cdot 2$ \\
\hline Orotic acid & $3 \cdot 88$ & $109 \cdot 8$ & Furfuryl alcohol & $0 \cdot 137$ & $90 \cdot 4$ \\
\hline Cytidylic acid & $1 \cdot 39$ & $68 \cdot 4$ & 2-Furaldehyde & $0 \cdot 135$ & $73 \cdot 7$ \\
\hline Adenylic acid & $0 \cdot 31$ & $267 \cdot 0$ & Hydrofuramide & $0 \cdot 159$ & 0.0 \\
\hline Thymidine & 0.293 & $103 \cdot 7$ & Furacin & 0.005 & $83 \cdot 1$ \\
\hline Uridine & 0.5 & $79 \cdot 8$ & Furadantin & 0.005 & $70 \cdot 3$ \\
\hline Adenine sulphate & $2 \cdot 11$ & $268 \cdot 9$ & Furoxone & $0 \cdot 005$ & $90 \cdot 2$ \\
\hline
\end{tabular}

Purines, pyrimidines and related compounds. The effects of derivatives of purines and pyrimidines and related compounds were examined; the results of these experiments are presented in Table 6. It is clear that adenine-containing compounds stimulated Poteriochromonas stipitata growth. The increase of total cell-N given by sodium ribonucleate and sodium deoxyribonucleate is explainable on the basis of their content of adenine. The increased yields obtained with hypoxanthine, uric acid, 
barbital and kinetin may be related to their structural similarity to adenine. Since kinetin was stimulatory, one wondered whether the effect might not also be a reflexion of the growth-promoting activity of this compound, similar to that observed in green plants. To this end, furan derivatives, which affect growth in plants, were tested (see Table 6). Of these, only furfurylamine exhibited stimulatory effects. The adenine moiety of kinetin, therefore, was probably responsible for the stimulation of $\boldsymbol{P}$. stipitata observed.

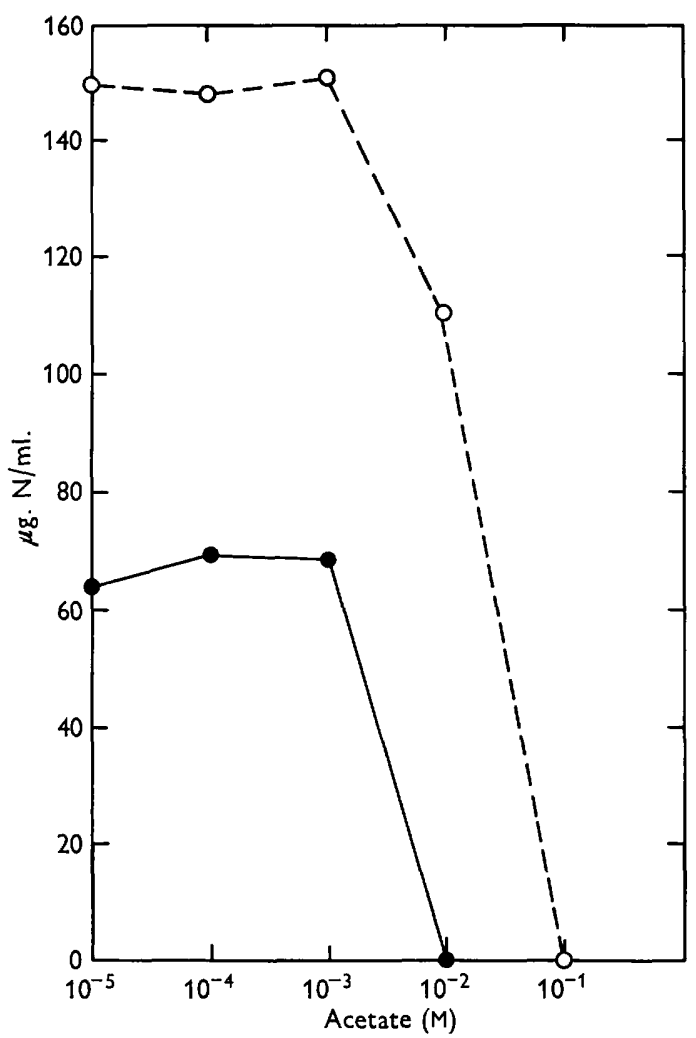

Fig. 2. Reaction of Poteriochromonas stipitata to increasing amounts of acetate at pH 5.0.

\section{Vitamin requirements}

The present work confirmed the vitamin $B_{12}$, thiamine and biotin requirements established by Hutner et al. (1953). No response was obtained with any of the other B vitamins, ascorbic acid or fat soluble vitamins. As can be seen in Fig. 3 the amount of the nutrient designated by Hutner et al. (1953) $(0.5 \times$ concentrations, Table 1) for freshwater chrysomonads was not in every case the optimum amount for Poteriochromonas stipitata. It had been noted earlier in the work that doubling the amount of the vitamin mixture increased the yields of organism. The $1 \times$ concentration in Fig. 3 reflects this doubling; the figure shows, however, that vitamin $B_{12}$ was most effective at a concentration originally suggested by Hutner (Hutner et al. 1953). Response to thiamine was similar to vitamin $B_{12}$. However, biotin was indeed 


\section{Nutrition of Poteriochomonas stipitata}

most stimulatory at the highest concentration tested. Table 7 , in which the omission of these materials is presented, revealed the absolute need for the 3 vitamins by the flagellate.

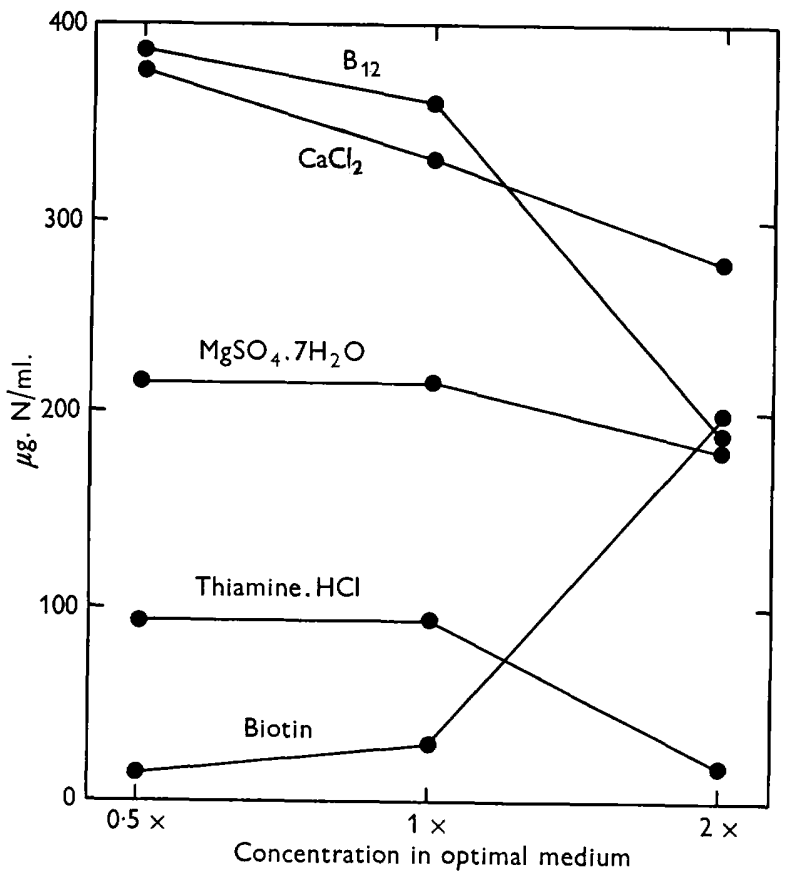

Fig. 3. The effect of varying vitamin and cation concentrations on cell-N yields of Poteriochromonas stipitata. The medium is the basal medium Eat pH 5.0. The $1 \times$ concentrations were as follows : vitamin $\mathrm{B}_{12}, 10 \mu \mathrm{g} . / 1$; thiamine $\mathrm{HCl}, 4 \mathrm{mg} . / \mathrm{l}$; biotin, $40 \mu \mathrm{g} . / 1$; $\mathrm{CaCl}_{2}$, $0.8 \mathrm{~g} . / \mathrm{l}$; $\mathrm{MgSO}_{4} .7 \mathrm{H}_{2} \mathrm{O}, 0.6 \mathrm{~g} . / 1$, , while $0.5 \times$ concentration represents their concentration in Hutner's medium (1951, see Table 1). Trace metals were added in their usual concentration.

\section{Table 7. The effect of omission of individual metals and vitamins on cell- $N$ yields of Poteriochromonas stipitata}

Basal medium E at $\mathbf{p H} 5 \cdot 0$ was used with illumination. All cations and vitamins were then added with the exception of the single substance under scrutiny. The results were the average of ten determinations with an error of less than $\pm 1.5 \%$

Total cell-N when

Usual concentration material was omitted

Substance omitted

$\mathrm{MgSO}_{4} \cdot 7 \mathrm{H}_{2} \mathrm{O}$

$\mathrm{CaCl}_{2}$

$\mathrm{ZnSO}_{4} \cdot 7 \mathrm{H}_{2} \mathrm{O}$

$\mathrm{MnSO}_{4} \cdot \mathrm{H}_{2} \mathrm{O}$

$\mathrm{CuSO}_{4} \cdot 5 \mathrm{H}_{2} \mathrm{O}$

$\mathrm{FeSO}_{4}(\mathrm{NH})_{2} \mathrm{SO}_{4} \cdot 6 \mathrm{H}_{2} \mathrm{O}$

$\mathrm{CoSO}_{4} \cdot 7 \mathrm{H}_{2} \mathrm{O}$

$\left(\mathrm{NH}_{4}\right)_{4} \mathrm{Mo}_{7} \mathrm{O}_{24} \cdot 4 \mathrm{H}_{2} \mathrm{O}$

Thiamine

Biotin

Cobalamine $\left(\mathrm{B}_{12}\right)$

None present (control)

All present (control)

$$
\text { (g./1.) }
$$

$0 \cdot 6$

$0 \cdot 24$

$0 \cdot 18$

$0 \cdot 18$

$0 \cdot 059$

$0 \cdot 042$

0.038

0.0007

0.004

0.00003

0.000015 ( $\%$ of positive control)

$\begin{array}{rr}\cdot & 11 \cdot 8 \\ . & 100 \cdot 0\end{array}$




\section{Mineral requirements}

Figure 3 also shows that calcium and magnesium elicited an optimal response at the concentrations advocated by Hutner et al. (1953). Table 7 shows the effect of the omission of cations from basal medium $\mathrm{E}$ (Table 1), which contained the same non-metabolizable chelating agent as basal medium A. Ethylenediaminetetra-acetate has admittedly low chelating efficiency at acid $\mathrm{pH}$ values with the alkaline earth metals, but it can still remove contaminating traces from those metals present. It became obvious that the most critical metal was iron. A lesser dependency on magnesium, calcium, cobalt and perhaps molybdenum was also evident. Zinc, manganese and copper may have exerted some toxic influence since their absence

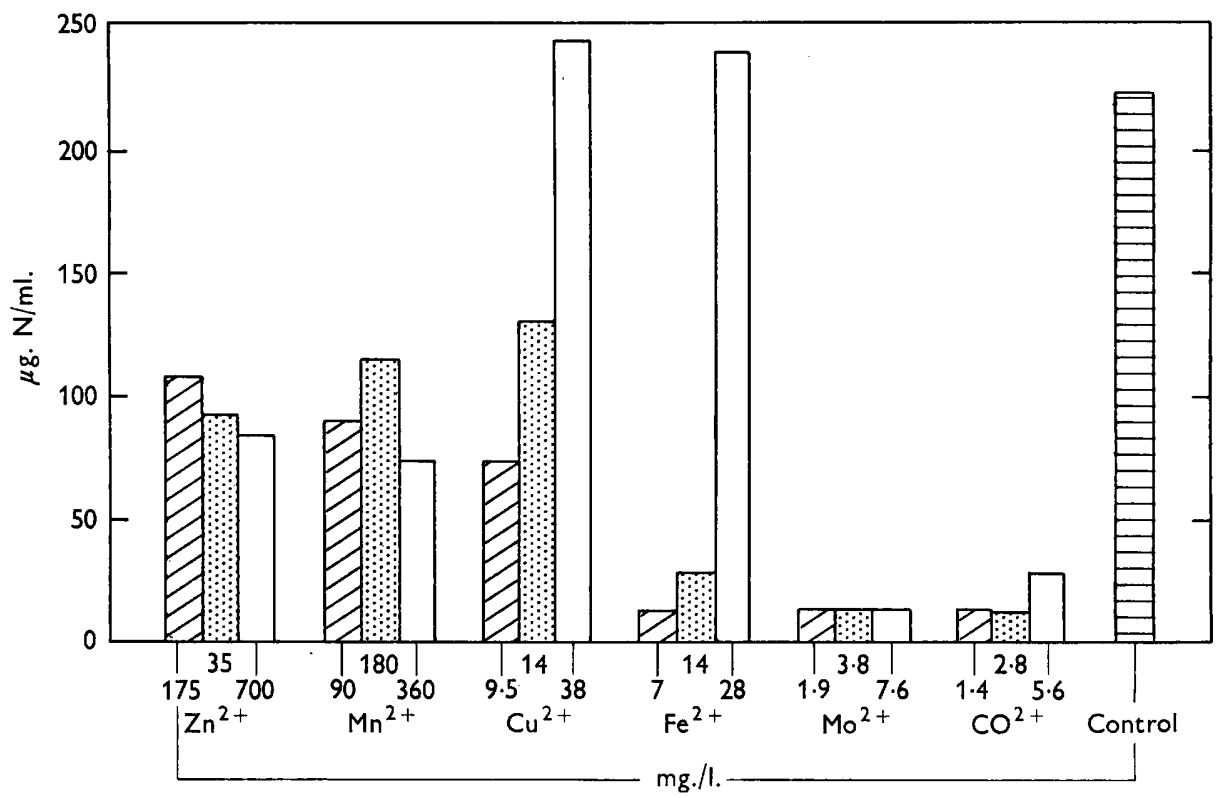

Fig. 4. The growth response of Poteriochromonas stipitata to varying concentrations of trace metals at $\mathrm{pH}$ 5.0 with illumination. The medium used corresponds to the one described in Table 7 to which were added thiamine. $\mathrm{HCl}, 2 \mathrm{mg} . / \mathrm{l}$; biotin, $0.02 \mathrm{mg} . /$., vitamin $\mathbf{B}_{12}$, $0.005 \mathrm{mg}$. $/ \mathrm{l}$; $\mathrm{CaCl}_{2}, 0.8 \mathrm{~g}$./1.; $\mathrm{MgSO}_{4} .7 \mathrm{H}_{2} \mathrm{O}, 0 \cdot 6 \mathrm{~g}$./1. For the control all trace metals were added in the amounts represented by the centre bar. The results were the average of ten determinations, with an error of less than $\pm 1.5 \%$.

resulted in slightly enhanced yields of organism. Addition of increasing amounts of trace metals confirmed these findings (Fig. 4). Zinc gave the best results in its lowest concentrations; manganese in the medium range; the concentration of cobalt mattered little. Molybdenum and copper, and especially iron, gave the best results in the highest concentrations tested. The findings with copper were surprising in view of the effect its absence exerted; repeated experiments gave similar results consistently. When optimal concentrations of trace metals were used a $50 \%$ increase in total cell-N over the control represented in Fig. 4 was obtained.

Hutner's defined medium (Hutner et al. 1953) contained 0.3 g. $\mathrm{KH}_{2} \mathrm{PO}_{4} / \mathrm{l}$. (Table $\mathbf{1}$ ). Figure 5 showed that yields of organism obtained with this amount were about $50 \%$ 
of those with $1 \mathrm{~g}$. phosphate/l.; this finding was independent of the cation used with the phosphate.

The medium proposed by Hutner et al. 1953 (Table 1) only supported the organism when the initial $\mathrm{pH}$ was about 5 . Using the media devised in the present work the organism grew well at $\mathrm{pH} 5$ and produced a final $\mathrm{pH}$ value of $\mathbf{3} \cdot \mathbf{3} \pm \mathbf{0 \cdot 3}$, regardless of substrate or nature of the carbon source. Duplicate samples were examined at 2-day intervals for 30 days. While the maximum yields of organism were obtained at different times from each medium, the final $\mathrm{pH}$ value was reached within 2 days and was identical for all.

It was found early in this work that Poteriochromonas stipitata could be maintained in thioglycollate broth (BBL) at $\mathrm{pH} 7$. All attempts to grow the organism in Hutner's defined medium (Hutner et al. 1953;) at this $\mathrm{pH}$ value failed, while the basal medium $\mathrm{B}$ supported the chrysomonad at $\mathrm{pH} 7$. The a priori hypothesis that the decreased oxidation-reduction potential found in thioglycollate broth enabled $P$. stipitata to grow near neutrality could not be proved by using compounds such as L-cystine, mercaptoethanol, glutathione, sodium sulphite, thioglycollate, L-cysteine and cystamine, either singly or in mixtures.

\section{Table 8. Tolerance of Poteriochromonas stipitata to ammonium salts at} acid and neutral $p H$ in basal medium $F$

\begin{tabular}{|c|c|c|c|c|c|}
\hline \multirow[b]{2}{*}{ Compound } & \multirow{2}{*}{$\begin{array}{l}\text { Concentration } \\
\text { of compound } \\
\quad\left(\times 10^{-3} \mathrm{M}\right)\end{array}$} & \multicolumn{2}{|c|}{$\mathrm{pH}$ value } & \multirow{2}{*}{$\begin{array}{l}\mu \mathrm{g} . \text { total } \\
\text { cell-N/ml. }\end{array}$} & \multirow{2}{*}{$\begin{array}{c}\text { Difference } \\
\text { pH7.0/pH5.0 } \\
(\%)\end{array}$} \\
\hline & & initial & final & & \\
\hline \multirow[t]{2}{*}{ Ammonium citrate } & $4 \cdot 7$ & $5 \cdot 0$ & $3 \cdot 6$ & $49 \cdot 0$ & • \\
\hline & & $7 \cdot 0$ & $\mathbf{3} \cdot \mathbf{8}$ & $\mathbf{3 7 \cdot 3}$ & 76 \\
\hline \multirow[t]{2}{*}{ Ammonium carbonate } & $5 \cdot 7$ & $5 \cdot 0$ & $2 \cdot 6$ & $65 \cdot 3$ & . \\
\hline & & $7 \cdot 0$ & $\mathbf{3} \cdot \mathbf{3}$ & $41 \cdot 2$ & 63 \\
\hline \multirow[t]{2}{*}{ Ammonium chloride } & $11 \cdot 4$ & $5 \cdot 0$ & $2 \cdot 7$ & 74.7 & - \\
\hline & & $7 \cdot 0$ & $3 \cdot 0$ & $74 \cdot 3$ & 100 \\
\hline \multirow[t]{2}{*}{ Ammonium sulphate } & $5 \cdot 7$ & $5 \cdot 0$ & $2 \cdot 7$ & $66 \cdot 9$ & - \\
\hline & & $7 \cdot 0$ & $\mathbf{3 \cdot 0}$ & $59 \cdot 5$ & 89 \\
\hline
\end{tabular}

However, the chrysomonad medium of Hutner et al. 1953 includes several amino acids, ammonium citrate and ammonium carbonate which are omitted from the defined media devised during the present work. This difference suggested that ammonia might exert a deleterious effect at $\mathrm{pH} 7$. Several ammonium salts (Table 1) were tested in the basal medium $\mathrm{F}$ at $\mathrm{pH} 5$ and $\mathrm{pH} 7$, resulting in findings summarized in Table 8 which illustrates the role played by ammonia in permitting protozoan growth at neutral $\mathrm{pH}$. The volatility of ammonia at $\mathrm{pH} 7$ was considerably depressed by the presence of the more acidic anions which would not only maintain ammonia in an ionized state but also make it available as a nitrogen source. When ammonium chloride, as sole nitrogen source, was added in increasing amounts to the basal medium $\mathrm{F}$ at $\mathrm{pH} 7$ (Fig. 6), no inhibition was demonstrable. Replacement of the ammonium ion by other forms of nitrogen in Hutner's defined medium (Hutner et al. 1953) resulted in increases in yield of total cell-N at pH 7 , even in the presence of the same concentration of citrate ion. Thus, while ammonium citrate in its usual concentration (Table 1) resulted in $20 \mu \mathrm{g}$. total cell-N/ml., urea $0.34 \mathrm{~g}$. $/ \mathrm{l}$. and sodium citrate $1.67 \mathrm{~g}$. $/$. increased yields to $31 \mu \mathrm{g}$. $/ \mathrm{ml}$. while $51.7 \mu \mathrm{g}$. of 


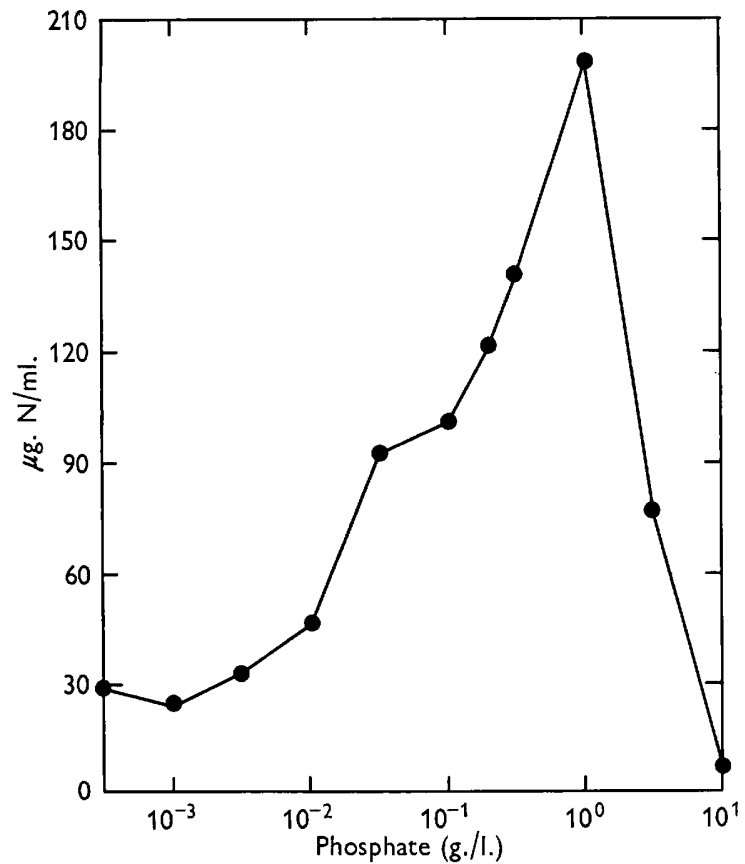

Fig. 5. The phosphate response of Poteriochromonas stipitata in basal medium $\mathrm{B}$ at $\mathrm{pH}$ 5.0 with illumination.

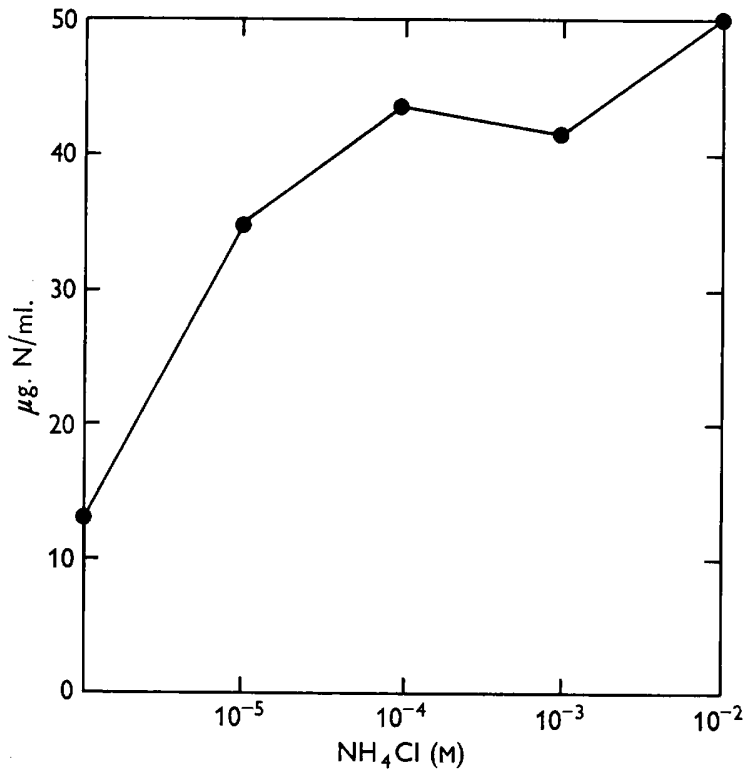

Fig. 6. The effect of ammonium chloride as only source of nitrogen in basal medium $\mathbf{F}$ at $\mathbf{p H} \mathbf{7} \cdot \mathbf{0}$. 
total cell-N $/ \mathrm{ml}$. were formed with sodium nitrate $0.97 \mathrm{~g} . /$. and sodium citrate $1 \cdot 67 \mathrm{~g} . / 1$.

The ammonium salts of weaker acids present in Hutner's defined medium (Hutner et al. 1953) offered only a partial explanation for the inability of the chrysomonad to grow at $\mathrm{pH} 7$. Comparison of that basal medium with basal medium $\mathrm{D}$ evolved in the present work showed the presence of additional organic nitrogen in

Table 9. The effect of organic nitrogen on the growth of Poteriochromonas stipitata in the presence and absence of ammonium citrate Experimental basal medium $D$ was used; the amino acids and citrate were present
in the concentrations found in Hutner's defined medium (Hutner et al. 1953).

\begin{tabular}{|c|c|c|c|}
\hline \multicolumn{4}{|c|}{$\mathrm{pH}$ values } \\
\hline & & & \\
\hline $\begin{array}{l}\text { Ammonium } \\
\text { present }\end{array}$ & $\begin{array}{l}\text { Citrate } \\
\text { absent }\end{array}$ & $\begin{array}{c}\text { Ammonium } \\
\text { present }\end{array}$ & $\begin{array}{l}\text { Citrate } \\
\text { absent }\end{array}$ \\
\hline
\end{tabular}

Yield of organism ( $\mu$ g. total cell-N/ml. medium)

L-Arginine
L-Glutamic acid
DL-Histidine
DL-Methionine
Control

$\begin{array}{rrrr}161 \cdot 8 & 152 \cdot 46 & 15 \cdot 4 & 23 \cdot 4 \\ 159.5 & 81 \cdot 6 & 92 \cdot 5 & 90 \cdot 0 \\ 161 \cdot 0 & 127 \cdot 4 & 12 \cdot 4 & 96 \cdot 3 \\ 143.9 & 107.7 & 4.7 & 52.5 \\ 77 \cdot 0 & 75 \cdot 0 & 65.7 & 65 \cdot 3\end{array}$

Table 10. The effect of amino nitrogen on Poteriochromonas stipitata at $\mathrm{pH} 7 \cdot 0$ in basal medium $D$

\begin{tabular}{|c|c|c|c|}
\hline \multirow[b]{2}{*}{ Compound } & \multicolumn{3}{|c|}{$\mu \mathrm{g}$ total cell- $\mathrm{N} / \mathrm{ml} .$, medium } \\
\hline & Alone & $\begin{array}{c}\text { Ammonium } \\
\text { citrate, } \\
1.2 \mathrm{~g} . / 1\end{array}$ & $\begin{array}{l}\mathrm{NH}_{4} \mathrm{Cl}, \\
0.57 \mathrm{~g} . / \mathrm{l} .\end{array}$ \\
\hline Glutamic acid* & $38 \cdot 1$ & $8 \cdot 4$ & $52 \cdot 5$ \\
\hline L-Arginine $\mathbf{H C l}$ & $87 \cdot 2$ & $7 \cdot 8$ & $59 \cdot 3$ \\
\hline DL-Histidine & $45 \cdot 1$ & $9 \cdot 4$ & $40 \cdot 8$ \\
\hline DL-Methionine & $\mathbf{3 6} \cdot \mathbf{5}$ & $7 \cdot 7$ & $53 \cdot 0$ \\
\hline DL-Ornithine $\mathrm{HCl}$ & $108 \cdot 1$ & $5 \cdot 6$ & $45 \cdot 1$ \\
\hline DL Citrulline & 63.8 & $7 \cdot 3$ & $30 \cdot 0$ \\
\hline L-Lysine HCl & $80 \cdot 1$ & $6 \cdot 6$ & $33 \cdot 5$ \\
\hline Glycine & $51 \cdot 4$ & $6 \cdot 4$ & $35 \cdot 4$ \\
\hline L-Cysteine $\mathbf{H C l}$ & $74 \cdot 6$ & $15 \cdot 2$ & $22 \cdot 5$ \\
\hline L-Glutamine & $43 \cdot 7$ & $3 \cdot 6$ & $26 \cdot 5$ \\
\hline L-Asparagine & $53 \cdot 6$ & $7 \cdot 4$ & $27 \cdot 2$ \\
\hline Control & $51 \cdot 9$ & $47 \cdot 9$ & $54 \cdot 8$ \\
\hline
\end{tabular}

the form of L-arginine $\mathrm{HCl} \mathrm{0.4} \mathrm{g./l.,} \mathrm{L-glutamic} \mathrm{acid} 3 \cdot 0$ g./l., DL-histidine 1.0 g./l., and DL-methionine $0.6 \mathrm{~g}$./l. The effect of these compounds on total cellular $\mathbf{N} / \mathrm{ml}$. in the basal medium $\mathrm{D}$ at $\mathrm{pH} 5$ and $\mathrm{pH} 7$ was tested in the presence and absence of ammonium citrate (Table 9). It is quite evident that although at $\mathrm{pH} 5$ the nitrogen sources were all utilizable and omission decreased the amount of total cell-N/ml., at pH 7 amino acids such as arginine, histidine and methionine were especially detrimental to protozoan proliferation in the presence of ammonium citrate. Additional 
evidence that amino acid nitrogen enhanced ammonia toxicity was sought experimentally by increasing the concentration of the amino acids added in the basal medium $D$ to $1.0 \mathrm{~g}$./1. Other amino acids, including the dibasic ones, and the amides of dicarboxylic amino acids were included. The action of these amino acids was evaluated in the presence of ammonium chloride and compared with results obtained with ammonium citrate at $\mathrm{pH} 7$. Table 10 shows that the increase in amino acid concentration resulted in good yields of organism in the absence of ammonium salts. The presence of ammonium citrate led to almost complete cessation of growth; decreased yields of organism were observed with equimolar ammonium chloride. The deleterious effect of ammonia was even shown by substituting the monosodium salts of dicarboxylic acids for the acid, as shown with monosodium glutamate in Table 10. This suggests that any substance capable of shifting the $\mathrm{pH}$ toward neutrality favours the conversion of ammonium ion to ammonia which results in toxic effects.

\section{DISCUSSION}

The nutritional requirements of Poteriochromonas stipitata can be considered in three categories (Table 11). The basal or most essential nutrients could not be replaced

Table 11. The nutritional requirements of Poteriochromonas stipitata

Compound g./l. Compound g./l.

Essential nutrients (to obtain 10-20 $\mu \mathrm{g} . / \mathrm{ml}$. total cell-N)

\begin{tabular}{|c|c|}
\hline Glucose* & $10 \cdot 0$ \\
\hline $\mathrm{NH}_{4} \mathrm{Cl} \uparrow$ & $1 \cdot 0$ \\
\hline $\begin{array}{l}\text { Ethylenediaminetetra- } \\
\text { acetic acid } \$\end{array}$ & $0 \cdot 64$ \\
\hline $\mathrm{KH}_{2} \mathrm{PO}_{4}$ & $0 \cdot 03$ \\
\hline $\mathrm{CaCl}_{2}$ & 0.08 \\
\hline $\mathrm{MgSO}_{4} \cdot 7 \mathrm{H}_{2} \mathrm{O}$ & $0 \cdot 06$ \\
\hline Thiamine $\mathrm{HCl}$ & $2.0 \mathrm{mg}$. \\
\hline Biotin & $0.02 \mathrm{mg}$. \\
\hline Vitamin $\mathbf{B}_{12}$ & $0.005 \mathrm{mg}$. \\
\hline $\mathrm{ZnSO}_{4} \cdot \mathrm{H}_{2} \mathrm{O}$ & $175 \cdot 0 \mathrm{mg}$. \\
\hline $\mathrm{MnSO}_{4} \cdot \mathrm{H}_{2} \mathrm{O}$ & $184 \cdot 6 \mathrm{mg}$. \\
\hline $\mathrm{CuSO}_{4} \cdot 5 \mathrm{H}_{2} \mathrm{O}$ & $39.0 \mathrm{mg}$. \\
\hline $\mathrm{FeSO}_{4}\left(\mathrm{NH}_{4}\right)_{2} \mathrm{SO}_{4} \cdot 6 \mathrm{H}_{2} \mathrm{O}$ & $28 \cdot 1 \mathrm{mg}$. \\
\hline $\mathrm{CoSO}_{4} \cdot 7 \mathrm{H}_{2} \mathrm{O}$ & $1.9 \mathrm{mg}$. \\
\hline$\left(\mathrm{NH}_{4}\right)_{6} \mathrm{Mo}_{7} \mathrm{O}_{24} \cdot 4 \mathrm{H}_{2} \mathrm{O}$ & $1.4 \mathrm{mg}$. \\
\hline
\end{tabular}

Adequate nutrition (to obtain at least $100 \mu \mathrm{g}$./ ml. total cell-N)§

$\begin{array}{ll}\text { L-Isoleucine } & 0 \cdot 5 \\ \text { L-Valine } & 0.5 \\ \text { L-Leucine } & 0.5 \\ \text { L-Phenylalanine } & 0.5\end{array}$

Optimal nutrition (to obtain in excess of $200 \mu \mathrm{g} . / \mathrm{ml}$. total cell-N)\|

$\begin{array}{lr}\text { Glucose } & 10 \cdot 0 \\ \mathrm{KH}_{2} \mathrm{PO}_{4} & 0 \cdot 7 \\ \text { Adenine sulphate } & 0 \cdot 5 \\ \text { L-Glutamic acid } & 0 \cdot 6 \\ \text { L-Histidine } & 0 \cdot 1 \\ \text { L-Arginine } & 0 \cdot 1\end{array}$

$\mathrm{pH} 7.0$ or 5.0 ; incubated in the presence or absence of light.

* Other suitable carbon sources may be substituted.

$\dagger$ Urea, nitrate or most casein amino acids may be substituted in equimolar amounts.

$\ddagger$ This compound, though not metabolized, required listing since it is essential for maintaining minerals in a utilizable state.

$\S$ Added to the essential nutrients.

II Added to all previously listed nutrients.

or diminished in concentration to any great degree; the yields of organisms on this basal medium were equivalent to $10-20 \mu \mathrm{g}$. total $-\mathrm{N} / \mathrm{ml}$. medium. The addition of a few amino acids in moderate amounts led to a disproportionate increase (5-30-fold) of protozoan growth relative to the amounts of nitrogen and carbon supplied; other amino acids supplied in similar amounts failed to achieve the 5-30-fold increase in yield. The response of the organism was modified still further by adding more carbon and phosphate as well as additional amino acids and adenine. These latter supple- 
ments resulted in at least a further doubling of total cell-N. The presence or absence of light and maintenance of acid or neutral $\mathrm{pH}$ values did not appear to influence the yields of $\boldsymbol{P}$. stipitata to any degree.

It seems doubtful whether Poteriochromonas stipitata encounters these optimal concentrations and kinds of nutrient in nature. Indeed, it is found experimentally that the less-than-optimal nutrition produces protozoa less sensitive to toxic materials introduced into the environment (Isenberg, Berkman \& Sundehim, 1962); nevertheless the upper and lower limits of nutritional response should be established.

The ability to utilize exogenous material is a first approximation of the physiology and biochemistry of an organism (Knight, 1936). The limited number of compounds which serve Poteriochromonas stipitata as carbon and energy sources reveal the biochemical limitations of this organism. No $\beta$-glycosidases could be demonstrated. However, the organism was able to utilize all $\alpha$-glycosides supplied. When high concentrations of starch $(200 \mathrm{~g}$./1.) were used in an attempt to cultivate the phytoflagellate on a solid medium, liquefaction of the starch gel was rapid, suggesting the production of an amylase. Similarly, proteinases were produced, as indicated by rapid liquefaction of gelatin media. Further evidence for the elaboration of extracellular proteinases and peptidases was given by the variety of proteins and peptides which could supply the nitrogen requirements of the organism. The production of extracellular enzymes apparently supplements the phagotrophic capacities of this chrysomonad. The organism's ability to utilize glucose and galactose with equal ease is interesting, especially since none of the pentoses are utilized. The selectivity of the cell with respect to tri-carboxylic acid cycle compounds and intermediates of hexose oxidation, and fatty acid metabolism is noteworthy in view of the ease with which glycerol, acetate and ethanol were metabolized. Glycerol utilization especially warrants attention. P. stipitata and Ochromonas malhamensis have been considered 'sugar' flagellates (Pringsheim, 1952). Yet the better yields obtained with glycerol suggest that this compound may be a preferred carbon source. Since, in addition, gradual loss of chlorophyll function is an outstanding characteristic of these organisms (Pringsheim, 1952; Wolken \& Schwartz, 1953), these 'most primitive animals' (Hutner \& Provasoli, 1951), may reflect another step in the evolution of heterotrophic chemo-organotrophy (Lwoff, 1951) from autotrophic or mesotrophic autotrophy in protozoa. While acetate was not tolerated in concentrations resembling those of 'acetate flagellates' (Hutner \& Provasoli, 1951), the concentrations of glucose found optimal were more suggestive of fungal physiology. Phase-contrast microscopy of $\boldsymbol{P}$. stipitata cells grown on such a high carbohydrate diet revealed large storage bodies which were lacking in cells grown in thioglycollate broth. In manometric studies, not reported here, cells with such inclusions showed prolonged enhanced endogenous respiration.

The present work indicates that ammonia and urea or nitrate can supply the nitrogen requirements of Poteriochromonas stipitata. The rate of growth is influenced markedly by the presence of certain amino acids; the most important of these, leucine, isoleucine, valine, phenylalanine, are all ketogenic. Their importance as nutrients seems more likely to be a reflexion of the branched or aromatic nature of their carbon skeletons. The other amino acids and adenine which promoted optimal growth probably reflect the greater ease with which organisms grow in the presence of non-essential amino acids (Oginsky \& Umbreit, 1959). 
This investigation was supported in part by United States Public Health Service Grant CY-3110; the findings reported are taken from a thesis submitted to the Graduate School of St John's University in partial fulfilment of the requirement for the degree of Doctor of Philosophy.

\section{REFERENCES}

Hutner, S. H. \& Provasoli, L. (1951). The phytoflagellates. In Biochemistry and Physiology of Protozoa, Vol. 1, p. 29. Ed. by A. Lwoff. New York: Academic Press Inc.

Hutner, S. H., Provasoli, L. \& Filfus, J. (1953). Nutrition of some phagotrophic fresh water chrysomonads. Ann. N.Y. Acad. Sci. 56, 852.

Isenberg, H. D., Berkman, J. I. \& Sundehim, L. H. (1962). The response of Poteriochromonas stipitata to urethan and related compounds. J. Protozool. (in the Press.)

KNIGHT, B. C. J. G. (1936). Bacterial nutrition. Material for a comparative physiology of Bacteria. Spec. Rep. Ser. med. Res. Coun., Lond. London: H.M. Stationery Office.

LwoFf, A. (1951). Introduction to biochemistry of protozoa. In Biochemistry and Physiology of Protozoa, Vol. 1, p. 1. Ed. by A. Lwoff. New York: Academic Press, Inc.

Oginsky, E. L. \& Umbreit, W. W. (1959). An Introduction to Bacterial Physiology. 2nd ed. San Francisco: W. H. Freeman and Co.

Pringsheim, E. G. (1952). On the nutrition of Ochromonas. Quart. J. micr. Sci. 93, 71.

Strain, H. H. (1949). Functions and properties of the chloroplast pigments. In Photosynthesis in Plants, p. 133. Ed. by J. Frank and W. E. Loomis. Ames, Iowa: Iowa State College Press.

Umbriet, W. W., Burris, R. H. \& Stauffer, J. R. (1957). Manometric Techniques, p. 274. Minneapolis: Burgess Publishing Co.

van Wagtendonk, W. J. (1955). The nutrition of ciliates. In Biochemistry and Physiology of Protozoa, Vol. 2, p. 57. Ed. by S. H. Hutner \& A. Lwoff. New York: Academic Press, Inc.

Wolken, J. J. \& Palade, G. E. (1953). An electron microscope study of two flagellates. Chloroplast structure and variation. Ann. N.Y. Acad. Sci. 56, 873.

Wolken, J. J. \& Schwartz, F. A. (1953). Chlorophyll monolayers in chloroplasts. J. gen. Physiol. 37, 111. 